\title{
Role of Two Recently Cloned Rat Liver GSH Transporters in the Ubiquitous Transport of GSH in Mammalian Cells
}

\author{
Shelly C. Lu, Wei-Min Sun, Jian Yi, Murad Ookhtens, Gloria Sze, and Neil Kaplowitz \\ Division of Gastrointestinal and Liver Diseases, Department of Medicine, University of Southern California School of Medicine, \\ and the Department of Veteran Affairs Outpatient Clinic, Los Angeles, California 90033
}

\begin{abstract}
Recently our laboratory has cloned both the rat canalicular and sinusoidal GSH transporters (RcGshT and RsGshT, respectively; Yi, J., S. Lu, J. Fernandez-Checa, and N. Kaplowitz. 1994. J. Clin. Invest. 93:1841-1845; and 1995. Proc. Natl. Acad. Sci. USA. 92:1495-1499). The current work characterized GSH transport and the expression of these two GSH transporters in various mammalian cell lines. The average cell GSH levels (nmol/10 $10^{6}$ cells) were $25,22,32,13$, and 13 in HepG2, HeLa, CaCo-2, MDCK, and Cos-1 cells, respectively. GSH efflux was temperature dependent and averaged $0.018,0.018,0.012,0.007$, and $0.019 \mathrm{nmol} / 10^{6}$ cells/min from HepG2, HeLa, CaCo-2, MDCK, and Cos-1 cells, respectively. Dithiothreitol (DTT), which stimulates rat sinusoidal GSH efflux, stimulated GSH efflux only in HepG2 and HeLa cells which was partially reversed by subsequent cystine treatment. GSH uptake (1 mM plus $\left.{ }^{35} \mathrm{~S}-\mathrm{GSH}\right)$ was temperature dependent, linear up to $45 \mathrm{~min}$, and $\mathrm{Na}^{+}$independent with average rates of $1.12,0.91,0.45$, and 0.45 $\mathrm{nmol} / 10^{6}$ cells/30 min for HepG2, HeLa, CaCo-2, MDCK, and Cos- 1 cells, respectively. BSP-GSH ( $2 \mathrm{mM})$, which cisinhibits sinusoidal GSH uptake in rat liver and HepG2 cells, inhibited GSH uptake only in HeLa cells. mRNA and polypeptide of RcGshT are expressed in all cells whereas those of RsGshT are expressed only in HepG2 and HeLa cells. In conclusion, bidirectional GSH transport, mediated by the "canalicular" GSH transporter, is ubiquitous in mammalian cells. Sinusoidal GSH transporter expression is more restricted, being present in HepG2 and HeLa cells. DTT and BSP-GSH affect GSH transport only in cells expressing the sinusoidal transporter confirming their selective action on this transporter. (J. Clin. Invest. 1996. 97: 1488-1496.) Key words: RcGshT • RsGshT • HepG2 • HeLa - $\mathrm{CaCo}-2 \cdot \mathrm{MDCK} \cdot \mathrm{Cos}-1$
\end{abstract}

\section{Introduction}

Glutathione (GSH) is recognized as a critical factor in cell defense $(1,2)$. In addition, it has been suggested that GSH is a stable, nontoxic storage and transfer vehicle for cysteine $(1,2)$. To accomplish this function, cysteine is incorporated into GSH

Address correspondence to Shelly C. Lu, Division of Gastrointestinal and Liver Diseases, MUDD Bldg. Rm 410, USC School of Medicine, 1333 San Pablo St., Los Angeles, CA 90033. Phone: 213-342-2441; FAX: 213-342-3243.

Received for publication 23 November 1994 and accepted in revised form 4 January 1996.

J. Clin. Invest.

(C) The American Society for Clinical Investigation, Inc. 0021-9738/96/03/1488/09 \$2.00

Volume 97, Number 6, March 1996, 1488-1496 in the cytosol of virtually all cells (synthesis) and is recovered from GSH by the hydrolytic activity of $\gamma$-glutamyltransferase $(\mathrm{GGT})^{1}$ and dipeptidase (breakdown). However, both these enzymes involved in the breakdown of GSH are integral membrane proteins with active sites on the outside of the plasma membrane. Therefore, for GSH to liberate cysteine, GSH must be released from cells. Although nearly all cells release $\mathrm{GSH}$, which determines basal turnover rate of GSH of each, the mechanism of release is not well understood. Since GSH is a hydrophilic molecule, it would not be expected to simply diffuse out of cells through the lipid bilayer of the plasma membrane. However, the concentration within cells is $2-3$ orders of magnitude greater than the exterior and it is theoretically possible that passive diffusion through a channel might be the mechanism for efflux from certain cells. The physiology of carrier mediated GSH transport (efflux) has been most extensively and almost exclusively characterized in hepatocytes and it is uncertain if similar mechanisms exist in various other mammalian cells. Thus, although efflux of GSH occurs, it is not certain if it is always carrier mediated.

Hepatocytes have been characterized as having at least two functionally distinct GSH carriers which govern efflux into blood and bile $(1,3)$. Our laboratory has successfully cloned two of these transports from rat liver cDNA libraries $(4,5)$. Both transporters exhibit low affinity (high $K_{\mathrm{m}}$ ), bidirectional, Na-independent GSH transport, and they show no sequence homology and represent two unique genes. The sinusoidal GSH transporter mRNA was only expressed in liver whereas the canalicular transporter mRNA was found in all organs examined $(4,5)$. The functional distinction between these two transporters relies on the selective cis-inhibitory effect of BSPGSH on the sinusoidal GSH transporter but not the low affinity canalicular GSH transporter (3-6). Another feature of the sinusoidal GSH transporter is its sensitivity to thiol modifying agents such that thiol reduction with dithiothreitol (DTT) led to increased GSH efflux from hepatocytes while inhibiting uptake, favoring outward movement of GSH while the opposite was observed with thiol oxidation $(7,8)$. Various mammalian cell lines have been used in research as representative of cells and tissues. Given the importance of GSH and the ubiquitous nature of GSH efflux in determining cell GSH turnover, it is important to elucidate the mechanism of GSH transport in a wide range of cells and to relate these findings to expression of the mRNA and polypeptide for the two rat liver GSH trans-

1. Abbreviations used in this paper: $\mathrm{BSO}, \mathrm{DL}-\mathrm{Buthionine-S-R-Sulfox-}$ imine; BSP, sulfobromophthalein; BSP-GSH, sulfobromophthalein GSH adduct; DBSP, phenol-3,6-dibromphthalein disulfonate; DIDS, 4,4'-diisothiocyanatostilbene-2,2'-disulfonic acid; GAPD, glyceraldehyde-3-phosphate dehydrogenase; LDH, lactate dehydrogenase; GGT, $\gamma$-glutamyl transpeptidase; MeAIB, $\alpha$-aminoisobutyric acid; RcGshT, rat canalicular GSH transporter; RsGshT, rat sinusoidal GSH transporter; SAF, sulfur amino acid free DME/F12. 
porters. At the same time, the actions of some factors which modify GSH transport in liver, such as thiol and disulfide modifying agents, can be related to the possible expression of one or both rat liver GSH transporters in order to determine if their actions are selective for either transporter.

\section{Methods}

Materials. GSH, bovine serum albumin, NADPH, 5,5'-dithiobis (2-nitrobenzoic acid), sodium EDTA, GSH reductase, fetal bovine serum (FBS), L-(S-5S)- $\alpha$-amino-3-chloro-4,5-dihydro-5-isoxazoleacetic acid (acivicin), DL-Buthionine-S-R-Sulfoximine (BSO), $p$-nitroaniline, glycylglycine, $\mathrm{L}-\gamma$-glutamyl- $p$-nitroanilide, $\alpha$-aminoisobutyric acid (MeAIB), threonine, tetramethylammonium (TMA) chloride, DTT, 4,4'-diisothio-cyanatostilbene, 2,2'-disulfonic acid (DIDS) and Hepes were purchased from Sigma Chemical Co. (St. Louis, MO). Dulbecco's modified Eagle's (DME) and minimal essential modified Eagle's (MEM) medium were purchased from Cellgro (Fisher Scientific, Pittsburgh, PA). Custom-made sulfur amino acid free DME/F12 medium (SAF) was purchased from Irvine Scientific (Irvine, CA). $\left[{ }^{35} \mathrm{~S}\right]$ Glutathione $(267 \mathrm{Ci} / \mathrm{mmol})$ and ${ }^{32} \mathrm{P}-\mathrm{dCTP}(3,000 \mathrm{Ci} / \mathrm{mmole})$ were obtained from DuPont (Wilmington, DE). Total RNA isolation kit was obtained from Promega (Madison, WI). Phenol-3,6-dibromphthalein disulfonate (DBSP) was obtained from Societe d'Etudes et de Recherches Biologiques (Paris, France). Sulfobromophthalein reduced GSH adduct (BSP-GSH) was enzymatically synthesized from the GSH S-transferase catalyzed reaction between GSH and sulfobromophthalein (BSP) under alkaline conditions as previously described (6). BSP-GSH was separated from unreacted BSP by acetone extraction and assayed at $580 \mathrm{~nm}$ under alkaline conditions. The conjugate was collected, lyophilized and stored at $-20^{\circ} \mathrm{C}$ until use. All other reagents were of analytical grade and were obtained from commercial sources.

Cell lines. HepG2, CaCo-2, MDCK, and Cos-1 cells were obtained from American Type Culture Collection (Rockville, MD). HeLa cells were kindly provided by Dr. James Ou (Department of Microbiology, USC School of Medicine). HepG2 cells are derived from a human hepatoblastoma and retain many of the differentiated features of mature hepatocytes (9). CaCo-2 cells are derived from a human colon carcinoma and have been a useful model for the study of intestinal epithelial function (10-13). MDCK cells are derived from distal tubular cells of a canine kidney which exhibit polarized functions $(14,15)$, Cos- 1 cells, derived from kidney of a monkey, exhibit fibroblast-like characteristics, and HeLa cells are derived from a human cervical carcinoma. All except MDCK cells were routinely cultured in DME medium (MDCK was in MEM medium) containing $10 \%$ FBS $(20 \%$ FBS in the case of CaCo-2), penicillin $(100 \mu \mathrm{g} / \mathrm{ml})$ and streptomycin $(0.1 \mathrm{mg} / \mathrm{ml})$ in a humidified atmosphere of $5 \% \mathrm{CO}_{2}$, $95 \%$ air and subcultured every 3-7 d at a cell density of $2 \times 10^{6}$ cells per $75 \mathrm{~cm}^{2}$ flask. Medium was changed every 3-4 d. Cells were discarded after subculturing for 5 mo and the original stock which had been frozen was thawed for continuation of culture. To study GSH transport, cells were detached by trypsin-EDTA $(0.05$ and $0.02 \%$, respectively) and $\sim 2 \times 10^{6}$ cells in $5 \mathrm{ml}$ medium were seeded on $60 \times$ $15 \mathrm{~mm}$ plastic dishes, at $37^{\circ} \mathrm{C}$ in $5 \% \mathrm{CO}_{2}-95 \%$ air atmosphere and studied $24 \mathrm{~h}$ later. To avoid the confounding variable of varying cell density, all of the transport studies were done using confluent cells. The viability of these cells was typically $>95 \%$ as determined by Trypan Blue exclusion.

GSH efflux. GSH efflux was measured as described previously (16). Confluent cells were washed with Krebs-Henseleit buffer, supplemented with $12.5 \mathrm{mM}$ Hepes ( $\mathrm{pH} 7.4)$, then incubating them in $5 \mathrm{ml} \mathrm{Krebs}$ at 37 or $4^{\circ} \mathrm{C}$ for $60 \mathrm{~min}$. Aliquots of supernatant $(500 \mu \mathrm{l})$ were removed at 5, 20, 40, and $60 \mathrm{~min}$ for GSH determination by the method of Tietze (17). The accumulation of GSH in the supernatant was linear over $60 \mathrm{~min}$; thus efflux rates were calculated by linear regression. In parallel experiments, cell lysis during the course of incu- bation was estimated by measuring the release of lactate dehydrogenase (LDH) (Sigma LDH kit) from the cytosol into the supernatant as a fraction of total cellular enzyme activity. Cell lysis was $<3 \%$ and did not increase during the 60 -min incubation. At the end of the experiments, cells were detached by trypsin-EDTA $(0.05 \%, 0.02 \%$, respectively) for cell counting by both Coulter counter and hemocytometer and analysis of viability which was $\geq 90 \%$ as determined by Trypan Blue exclusion. In addition, cell diameter was estimated by the Channelyzer (Coulter counter). Cellular GSH was extracted with $10 \%$ trichloroacetic acid solution and, after centrifugation at $13,000 \mathrm{~g}$ in a microfuge (Beckman Instruments) for $1 \mathrm{~min}$ to remove the denatured proteins, total GSH was measured by the method of Tietze (17) in the supernatant samples. To measure cellular LDH content, cells were scraped off with a rubber policeman, treated with $10 \%$ triton $\mathrm{X}-100$ in phosphate buffer saline $(1: 1, \mathrm{vol} / \mathrm{vol})$. After centrifugation in a microfuge, enzyme activity was measured according to the instruction described in the Sigma kit.

Measurement of GGT ecto-activity. GGT ecto-activity was measured by the release into the medium of $p$-nitroaniline from substrate L- $\gamma$-glutamyl- $p$-nitroanilide in intact culture according to the method described (16). Cells were rinsed with Krebs buffer and subsequently incubated in $5 \mathrm{ml} \mathrm{Krebs} \mathrm{buffer} \mathrm{with} \mathrm{L-glutamyl-p-nitroanilide} \mathrm{(1} \mathrm{mM)}$ and glycylglycine $(20 \mathrm{mM})$ at $37^{\circ} \mathrm{C}$ for an additional $30 \mathrm{~min}$. Aliquots of supernatant $(500 \mu \mathrm{l})$ were removed at 5,15 , and $30 \mathrm{~min}$ for measurement of GGT activity by release of $p$-nitroaniline. $p$-nitroaniline was measured by absorbance at $410 \mathrm{~nm}$ with concentrations derived from $p$-nitroaniline standard curve. Acivicin treatment did not result in increased cell lysis as determined by LDH release. Pretreatment of cells with $0.25 \mathrm{mM}$ acivicin for $30 \mathrm{~min}$ inhibited $98 \%$ of cell GGT activity thus $0.5 \mathrm{mM}$ acivicin pretreatment for $30 \mathrm{~min}$ was used for all efflux and uptake studies. GGT activity was expressed as nmol of $p$-nitroaniline released per $10^{6}$ cells per min.

GSH uptake. The technique used for measuring GSH uptake was as described previously (16). Cells were pretreated with acivicin $(0.5$ $\mathrm{mM}, 30 \mathrm{~min})$ and BSO (10 $\mathrm{mM}, 15 \mathrm{~min})$ in order to prevent breakdown of GSH and resynthesis of GSH from precursor, respectively. The medium used for washing and stopping uptake was $135 \mathrm{mM}$ $\mathrm{NaCl}, 1.2 \mathrm{mM} \mathrm{MgCl}, 0.81 \mathrm{mM} \mathrm{MgSO}$, $27.8 \mathrm{mM}$ glucose, $2.5 \mathrm{mM}$ $\mathrm{CaCl}_{2}$, and $25 \mathrm{mM}$ Hepes adjusted to $\mathrm{pH} 7.2$ with $\mathrm{NaOH}$. Transport medium was the same medium containing ${ }^{35} \mathrm{~S}-\mathrm{GSH}(2-4 \mu \mathrm{Ci} / \mathrm{ml}, 1 \mathrm{ml}$ per plate) and nonradioactive GSH (1 mM). Uptake buffer also contained $20 \mathrm{mM}$ each of MeAIB and threonine (inhibitors of amino acid transport systems A and ASC, respectively) to prevent any uptake of cysteine that may have resulted from breakdown of GSH. Cells were washed once $(2 \mathrm{ml})$ with prewarmed buffer and transport was initiated by addition of $1 \mathrm{ml}$ transport medium. After incubation at $37^{\circ} \mathrm{C}$ for the required time, uptake was terminated by washing twice ( $2 \mathrm{ml}$ each) with ice-cold buffer, followed by incubation with 1.5 $\mathrm{ml}$ of $5 \%$ bovine serum albumin mixed in buffer for another $5 \mathrm{~min}$ at $4^{\circ} \mathrm{C}$ to displace surface-bound radioactivity, this was followed by three more washes at $4^{\circ} \mathrm{C}(2 \mathrm{ml}$ each $)$. The washing procedure was validated by counting dpm in the supernatant after each wash. After the last wash, no radioactivity was recovered in the supernatant. Cells were then detached by trypsin-EDTA $(0.05 \%$ and $0.02 \%$, respectively); an aliquot was used for determining the radioactivity and another for cell number determination. To estimate trapping, uptake at $4^{\circ} \mathrm{C}$ (on ice) was studied in parallel. Duplicate plates were used for each time point and condition. Four degree count did not change with time of incubation and represented $21-50 \%$ of total counts $(\mathrm{HepG} 2=$ $43 \%, \mathrm{HeLa}=21 \%, \mathrm{CaCo}-2=50 \%, \mathrm{MDCK}=42 \%$, and Cos $-1=$ $39 \%)$. These were similar to values obtained for rat hepatocytes (8). The difference between 37 and $4^{\circ} \mathrm{C}$ uptake values represented true uptake.

GSH uptake was linear up to $45 \mathrm{~min}$ for all cells examined, thus all subsequent studies evaluating the effect of BSP-GSH, DBSP, DTT pretreatment, or removal of $\mathrm{Na}^{+}$were done with 30 min of incubation. For $\mathrm{Na}^{+}$free condition, TMA replaced $\mathrm{Na}^{+}$. The effect of DIDS was examined in HepG2 cells by pretreating cells with DIDS 
$(0.1 \mathrm{mM})$ for $30 \mathrm{~min}$ and subsequently adding DIDS $(0.1 \mathrm{mM})$ to GSH transport medium (containing $2 \mu \mathrm{Ci} / \mathrm{ml}{ }^{35} \mathrm{~S}-\mathrm{GSH}$ and $0.2 \mathrm{mM}$ unlabeled GSH). In some experiments, the molecular form of radioactivity inside the cell at the end of the uptake experiment was confirmed to be reduced GSH by radio-HPLC (see below). Uptake was expressed as nmoles of GSH per $10^{6}$ cells per 30 min.

To study the kinetics of GSH uptake, GSH uptake was measured as described above using ${ }^{35} \mathrm{~S}-\mathrm{GSH}(2-6 \mu \mathrm{Ci} / \mathrm{ml}, 1 \mathrm{ml}$ per plate $)$ and varying concentrations of nonradioactive GSH $(0.2-30 \mathrm{mM})$. To facilitate adjustment of osmolarity, transport buffer was changed to sucrose buffer containing $10 \mathrm{mM}$ Hepes (pH 7.4), $50 \mathrm{mM} \mathrm{NaCl}$ and varying concentrations of GSH. The concentration of sucrose was adjusted to maintain the osmolarity at $290 \mathrm{mOsm} / \mathrm{liter}$. GSH uptake measured with sucrose-based buffer was the same as measured using transport medium described above. At the end of uptake experiments, radio-HPLC confirmed that GSH in the transport buffer containing $0.2-1 \mathrm{mM}$ GSH remained in the reduced form. Kinetic analysis of GSH uptake was done as described previously $(8,16)$.

HPLC analysis. HPLC analysis was done according to the method of Fariss and Reed (18) using a Customsil, 3-aminopropyl Spherisorb, $4.6 \times 200 \mathrm{~mm}, 5-\mu \mathrm{m}$ column (CEL Associates, Houston, TX). The HPLC system consisted of a Shimadzu (Columbia, MD) gradient system with two LC-600 pumps, SCL-6B programmer/controller, SIL6B autosampler, SPD-6AV UV-visible detector, in series with a flowthrough B-RAM model 1A (IN/US, Tampa, FL) radiation detector, equipped with a 1-ml liquid scintillation cell, interfaced with a 386SX-16 microcomputer, Panasonic KX-01180 printer, and B-RAM software for UV and radioactive data acquisition, peak detection, and integration.

RNA isolation and Northern-blot analysis. RNA was isolated from various cell lines according to the method of Chomczynski and Sacchi (19). RNA $(20 \mu \mathrm{g})$ was separated on a $1 \%$ agarose gel with $6.7 \%$ formaldehyde, blotted onto a nylon membrane by capillary transfer, then hybridized to a $1.5-\mathrm{kb}$ cDNA derived from a subcloned insert corresponding to nucleotide $1132-2623$ of the rat canalicular GSH transporter (RcGshT) and to a full length 2.7-kb cDNA for the rat sinusoidal GSH transporter (RsGshT) as described previously $(4,5)$. The cDNA probes were labeled with ${ }^{32} \mathrm{P}-\mathrm{dCTP}$ by random priming (Primer-It II Kit; Stratagene, La Jolla, CA). Hybridization was at $42^{\circ} \mathrm{C}$ overnight in $50 \%$ formamide, $6 \times \operatorname{SSPE}(0.18 \mathrm{M} \mathrm{NaCl}, 10 \mathrm{mM}$ sodium phosphate, $\mathrm{pH} 7.7,1 \mathrm{mM}$ EDTA), 2\% SDS containing 100 $\mu \mathrm{g} / \mathrm{ml}$ salmon sperm DNA and $10^{7}$ dpm-labeled insert. Blots were washed twice for $10 \mathrm{~min}$ in $2 \times \mathrm{SSC}, 0.1 \% \mathrm{SDS}$ at room temperature, twice for $30 \mathrm{~min}$ in $0.1 \times \mathrm{SSC}(0.15 \mathrm{M} \mathrm{NaCl}, 0.015 \mathrm{M}$ sodium citrate, $\mathrm{pH} 7.0$ ), $0.5 \%$ SDS at $65^{\circ} \mathrm{C}$, then twice for $30 \mathrm{~min}$ in $0.1 \times \mathrm{SSC}$ at room temperature, and autoradiographed for 3-5 d onto Hyperfilm ${ }^{\circledR}$ (Amersham Corp., Arlington Heights, IL) using image-intensifying screens. To ensure equal loading of RNA samples, the same membrane was rehybridized with ${ }^{32} \mathrm{P}$-labeled rat glyceraldehyde-3-phosphate dehydrogenase (GAPD) cDNA (Clontech, Palo Alto, CA).

Western blot analysis of RcGshT and RsGshT. Rabbit polyclonal antibodies against synthetic peptides which correspond to amino acid residues 158-165 of RcGshT (4) and amino acid residues 188-196 of RsGshT (5) were used for Western blotting. The peptides were chosen according to the Hopp and Woods Hydrophilicity Scale (20). Both peptide synthesis and antibody generation were carried out by Bio-Synthesis, Inc. (Lewisville, TX). A cysteine was added at the $\mathrm{N}$-terminus and the peptide was conjugated to Keyhole Limpet Hemocyanin. Each rabbit received intramuscularly and subcutaneously $1.0 \mathrm{mg}$ of conjugate emulsified in Freund's complete adjuvant. At 6, 8, and 20 wk thereafter each rabbit received booster intramuscular immunization injections of $1.0 \mathrm{mg}$ conjugate in Freund's incomplete adjuvant. Antibody titers were determined by ELISA one week after each injection.

Protein extracts from the cell lines were used for Western blotting. Protein extracts containing $50 \mu \mathrm{g}$ protein were solubilized in equal volume of Sample buffer (285 mM Tris, $\mathrm{pH}$ 6.8, 30\% Glycerol, $6 \%$ SDS, $1.5 \%$ 2-mercaptoethanol and $0.01 \%$ Bromphenol Blue) and subjected to $10 \%$ SDS-PAGE (21) and electrotransferred to $0.2 \mu \mathrm{m}$ NitroCellulose membranes using Semidry Transfer Cell (Bio-Rad, Hercules, CA) (22). The NitroCellulose membranes were subsequently subjected to the Amplified Alkaline Phosphatase ImmunBlot Assay according to procedures described in the kit (Cat. No. 170-6412; Bio-Rad). The first antibody was either rabbit anti-rat RcGshT or anti-rat RsGshT peptide post-immune serum diluted $1: 250$ in TBST $(10 \mathrm{mM}$ Tris $\mathrm{pH} 8.0,150 \mathrm{mM} \mathrm{NaCl}$, containing $0.05 \%$ Tween 20). Preimmune serum showed no reactivity with cell extracts. The anti-RcGshT antiserum identified a $98-\mathrm{kD}$ polypeptide in canalicular-enriched membrane fraction but showed no reactivity with sinusoidal-enriched membrane fraction prepared from a pool of normal rat livers (not shown) according to the procedure of Meier et al. (23). Conversely, the anti-RsGshT antiserum identified a $38-\mathrm{kD}$ polypeptide in sinusoidal-enriched membrane fraction but showed no reactivity with canalicular-enriched membrane fraction.

Statistical analysis. For each experiment, means from duplicate plates were used for comparison, and the means of multiple experiments were compared by ANOVA followed by Fisher's test (multiple comparisons). The agreement between duplicate samples from each experiment was very high, generally $>90 \%$. Significance was defined as $P<0.05$.

\section{Results}

Comparison of cell GSH levels in different cell lines. Cell GSH levels (nmol/106 cells) were: 25 (HepG2), 23 (HeLa), 33 (CaCo-2), 14 (MDCK), and 15 (Cos-1). Freshly isolated rat hepatocytes are about $40-60 \mathrm{nmol} / 10^{6}$ cells. All of these cells are smaller than rat hepatocytes with cell volumes estimated to be $18-40 \%$ of rat hepatocytes, and all maintain at least comparable GSH concentrations to rat hepatocytes. Thus, efflux rates should not be limited by GSH availability.

Characterization of GSH efflux. All cell lines examined expressed GGT activity, with HepG2 expressing the highest GGT activity, followed by CaCo-2, HeLa, MDCK and Cos- 1 $(\mathrm{HepG} 2=11.2, \mathrm{CaCo}-2=3.68, \mathrm{HeLa}=3.22, \mathrm{MDCK}=1.73$, Cos- $1=0.87 \mathrm{nmol} / 10^{6}$ cells $/ \mathrm{min}$; results represent mean of at least two determinations which varied $<10 \%$ ). All were inhibited by $>98 \%$ with $0.25 \mathrm{mM}$ acivicin pretreatment for $30 \mathrm{~min}$. Thus, for all efflux experiments, cells were pretreated with 0.5 $\mathrm{mM}$ acivicin for $30 \mathrm{~min}$.

Of the five cell lines studied, we had previously characterized GSH efflux in HepG2 cells and found that efflux was unmasked by acivicin treatment, inhibited by BSP-GSH and cystathionine, and stimulated by cAMP-dependent agents (16), but whether DTT also stimulated efflux as in rat hepatocytes $(7,8)$ was not previously examined. To the best of our knowledge, no information exists on GSH efflux from the other four cell lines. We examined basal GSH efflux and the response to DTT and BSP-GSH, which is know to cis-inhibit sinusoidal GSH transport selectively $(3,6,24)$. Fig. 1 shows GSH efflux and effect of these agents in these five cell lines. All cells exhibited basal GSH efflux rates which translated to $2.3-4.7 \%$ of total cell GSH effluxed per hour (Fig. 1 C). GSH efflux rates were undetectable at $4^{\circ} \mathrm{C}$ for all cell lines. Pretreatment with DTT (2 mM for $30 \mathrm{~min}$ ) significantly increased GSH efflux $(\sim 400 \%)$ in both HepG2 and HeLa cells; whereas BSP-GSH ( $40 \mu \mathrm{M}$ pretreatment for $1 \mathrm{~h}$ and also present in Krebs buffer during efflux studies), inhibited GSH efflux in HepG2 cells but had no effect on any of the other cells.

We previously reported that cystine inhibited GSH efflux and partially reversed the stimulatory effect of DTT on GSH 


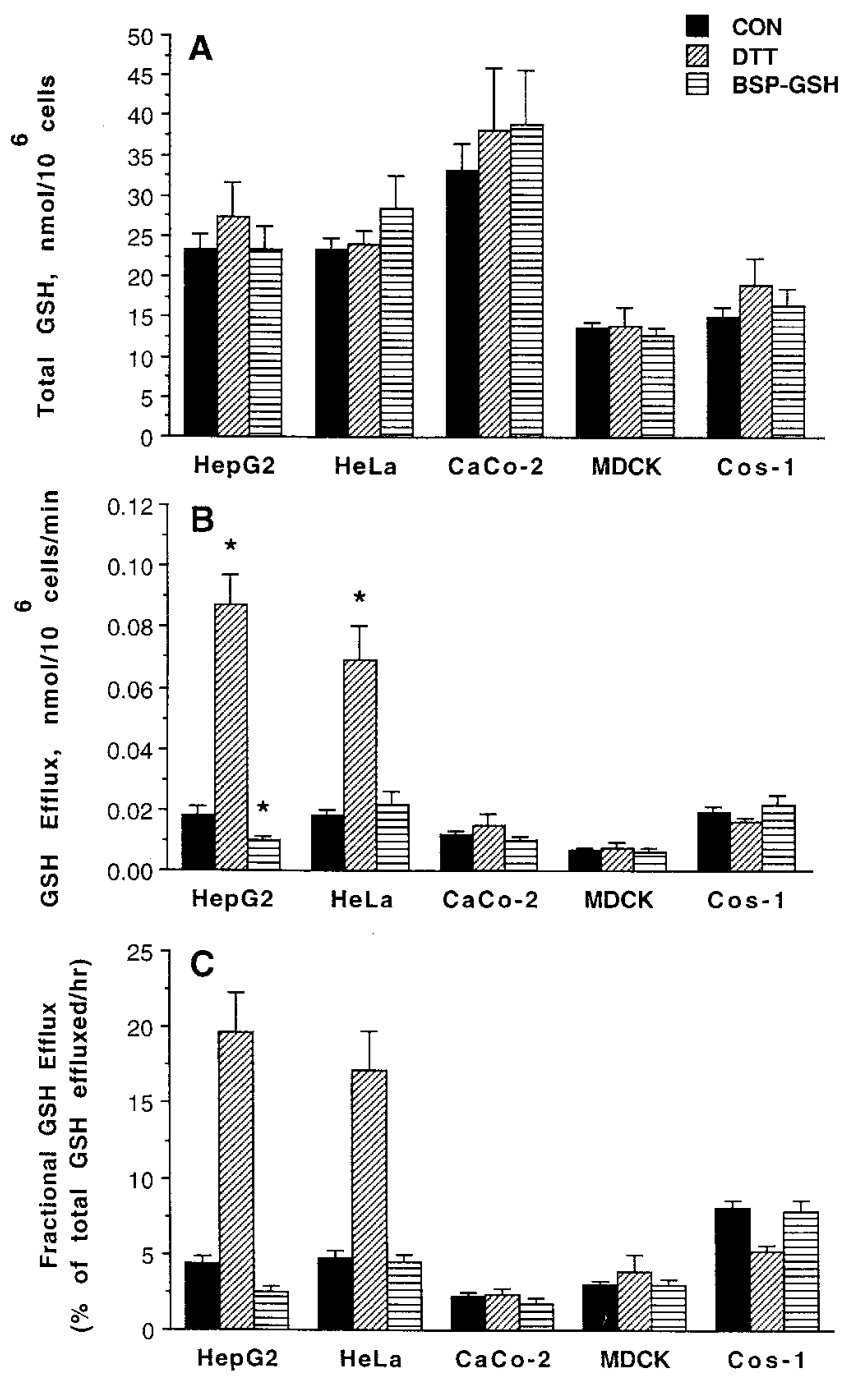

Figure 1. GSH efflux and effect of DTT, BSP-GSH in various cell lines. Cells were transferred one day prior to experiments from flasks to $60 \times 15$-mm petri dishes. GSH efflux was measured as described in Methods. Effect of DTT was examined by pretreating cells with DTT for $30 \mathrm{~min}$ followed by removal of DTT. The effect of BSP-GSH was examined by pretreating cells with $40 \mu \mathrm{M}$ BSP-GSH for $1 \mathrm{~h}$ and adding BSP-GSH back in the Krebs buffer during efflux. Results are expressed as mean $\pm \mathrm{SE}$ from 3 to 14 experiments for each cell line. Total GSH refers to the sum of cell and supernatant GSH (the same as cell GSH at the start of the efflux experiment since no GSH synthesis occurred in Krebs buffer). Fig. $1 A$ shows total GSH levels of various cell lines. Treatment with either DTT or BSP-GSH did not affect cell GSH. Fig. $1 B$ shows GSH efflux, expressed as nmol $/ 10^{6}$ cells $/ \mathrm{min}$. Note that DTT pretreatment significantly increased efflux only in HepG2 and HeLa cells. Fig. $1 C$ shows fractional GSH efflux, or percentage of total GSH that appeared per hour. (Fractional GSH efflux = percent of total GSH [cell + supernatant] that appeared in the supernatant per hour). $* P<0.05$ vs. control (CON) by ANOVA, followed by Fisher's test.

efflux in rat hepatocytes (7). Whether cystine can inhibit basal GSH efflux in HepG2 or HeLa cells could not be readily studied since these cells require cystine in the medium to support GSH synthesis (25) and the inhibitory effect of cystine in GSH efflux persists for at least $2 \mathrm{~h}$ after its removal (7). However, we were able to determine whether cystine could reverse the effect of DTT on GSH efflux. This was done by first pretreating HepG2 or HeLa cells with either DTT or vehicle for 30 min, then washing the cells twice and changing the medium to $\mathrm{SAF} \pm$ cystine $(1 \mathrm{mM})$ for $30 \mathrm{~min}$. This was followed by washing five times to remove cystine before measuring GSH efflux. The adequacy of this washing was confirmed by HPLC of the supernatant at the end of the efflux experiment which showed no GSH-cysteine mixed disulfide which would have formed had there been any cystine present (not shown). Table I shows that in both cell lines, the effect of DTT was partially reversed (by $\sim 50 \%$ ) by subsequent cystine treatment. Thus, similar to rat hepatocytes, GSH efflux in these two cell lines is also modulated by thiol-disulfide status. In cell lines not affected by DTT, such as $\mathrm{CaCo}-2$, the same experimental protocol (DTT treatment followed by cystine) exerted no influence on GSH efflux (data not shown).

Characterization of GSH uptake. We have previously demonstrated that HepG2 cells take up GSH by a $\mathrm{Na}^{+}$-independent mechanism which was competitively inhibited by BSPGSH (16). Very little characterization of GSH uptake has been reported in the other four cell lines. One recent article suggested that $\mathrm{CaCo}-2$ cells take up GSH since cellular GSH content increased after incubation with $1 \mathrm{mM}$ exogenous GSH (10). However, cells were not pretreated with acivicin or BSO so that breakdown and resynthesis of GSH were not ruled out. To characterize GSH uptake in the other four cell lines, we measured ${ }^{35} \mathrm{~S}-\mathrm{GSH}$ uptake in the presence of $1 \mathrm{mM}$ GSH and evaluated the effect of $\mathrm{Na}^{+}$-replacement, BSP-GSH which inhibits RsGshT but not RcGshT and DBSP. DBSP is a nonmetabolizable analogue of BSP which is known to inhibit canalicular GSH transport (26) and also inhibited GSH uptake in both sinusoidal and canalicular vesicles (Kaplowitz et al., unpublished observations) and inhibited the transport of GSH in oocytes expressing both RcGshT and RsGshT (5). This approach of assessing effect of inhibitors on GSH uptake has the

Table I. Effect of DTT and Cystine on GSH Efflux in HepG2 and HeLa Cells

\begin{tabular}{cclr}
\hline Condition & Total GSH & \multicolumn{2}{c}{ GSH Efflux Rate } \\
\hline & & & $\begin{array}{c}\text { Percent total } \\
\text { GSH } / h\end{array}$ \\
& $n m o l / 10^{6}$ cells & $n m o l / 10^{6}$ cells/min & \\
HepG2 Cells & & & $3.9 \pm 0.5$ \\
Vehicle-SAF & $31.9 \pm 2.3$ & $0.021 \pm 0.004$ & $2.6 \pm 0.7$ \\
Vehicle-SAC & $36.8 \pm 4.2$ & $0.015 \pm 0.004$ & $16.7 \pm 2.8$ \\
DTT-SAF & $27.7 \pm 2.1$ & $0.076 \pm 0.007^{*}$ & $8.9 \pm 0.8$ \\
DTT-SAC & $35.6 \pm 3.1$ & $0.052 \pm 0.002^{\ddagger}$ & \\
HeLa Cells & & & $3.5 \pm 0.3$ \\
Vehicle-SAF & $22.1 \pm 1.4$ & $0.013 \pm 0.001$ & $3.0 \pm 0.5$ \\
Vehicle-SAC & $22.9 \pm 2.9$ & $0.011 \pm 0.001$ & $11.8 \pm 1.8$ \\
DTT-SAF & $20.0 \pm 1.0$ & $0.039 \pm 0.005^{*}$ & $5.2 \pm 0.3$ \\
DTT-SAC & $24.4 \pm 2.7$ & $0.021 \pm 0.003^{\ddagger}$ & \\
& & &
\end{tabular}

Results are expressed as mean \pm SEM from 3-9 experiments. Cells, which had been transferred from flask to petri dishes the day before the experiment, were pretreated with DTT $(2 \mathrm{mM}, 30 \mathrm{~min})$ or vehicle, then washed twice and medium was changed to SAF or SAF + cystine $(1 \mathrm{mM}$, $\mathrm{SAC}$ ) for $30 \mathrm{~min}$. This was followed by washing five times and efflux was then measured in Krebs alone for $60 \mathrm{~min}$. Total GSH refers to the sum of cell plus supernatant GSH. $* P<0.05$ vs. control (vehicle-SAF); ${ }^{\ddagger} P<$ 0.05 vs. DTT-SAF by ANOVA. 
advantage of not depending on the ability of various cell types to take up the inhibitors as would be required to study cis-inhibition of efflux. As Fig. 2 illustrates, similar to HepG2 cells, all other cell lines also exhibited $\mathrm{Na}^{+}$-independent GSH uptake. DBSP inhibited GSH uptake in all cells, but BSP-GSH inhibited GSH uptake only in HepG2 and HeLa cells.

DIDS is known to inhibit a distinct high affinity GSH transporter in studies of GSH transport in rat canalicular membrane vesicle (27) while not affecting GSH transport by the cloned RcGshT and RsGshT (5). DIDS (0.1 mM) had no effect on GSH uptake $(0.2 \mathrm{mM})$ in HepG2 cells (control = $0.41 \pm 0.03$, DIDS $=0.37 \pm 0.03 \mathrm{nmol} / 10^{6}$ cells $/ 30 \mathrm{~min}$; results represent mean \pm SEM from three experiments).

Since we found that DTT converted the rat GSH transporter (presumably the sinusoidal transporter) from a bidirectional to a preferentially unidirectional (outward) transporter (8), we also examined whether the same occurred in the two cell lines in which GSH efflux was stimulated by DTT. As Fig. 3 shows, DTT pretreatment significantly inhibited GSH uptake in HepG2 and HeLa cells.

We next examined the kinetic parameters of GSH uptake in HeLa, CaCo-2, MDCK and Cos- 1 cells. We have previously shown that GSH uptake in HepG2 cells exhibited sigmoidal kinetics with a $K_{\mathrm{m}}$ of $2.36 \mathrm{mM}, V_{\max }$ of $4.15 \mathrm{nmol} / \mathrm{mg}$ per 30 min, and $\mathrm{n}$ (number of cooperative binding and/or transporter sites) of 1.54 (16), whereas GSH uptake in cultured rat hepatocytes exhibited nonsigmoidal (Michaelis-Menten) kinetics with a $K_{\mathrm{m}}$ of $7.7 \mathrm{mM}, V_{\max }$ of $24 \mathrm{nmol} / 10^{6}$ cells $/ 30 \mathrm{~min}$ (8). Fig. 4 summarizes the GSH uptake kinetics in these other four cell lines. The $K_{\mathrm{m}}$ was lower in HeLa cells $(4.47 \mathrm{mM})$ and was $\sim 6$ $\mathrm{mM}$ in $\mathrm{CaCo}-2$, MDCK and Cos- 1 cells. In comparison, oocytes injected with cRNA prepared from RsGshT and RcGshT exhibited $K_{\mathrm{ms}}$ of 2.87 and $6.59 \mathrm{mM}$, respectively for GSH uptake (5). The number of binding/transport sites $(n)$ for all of these fits were $>1$ suggesting a sigmoidal relationship between

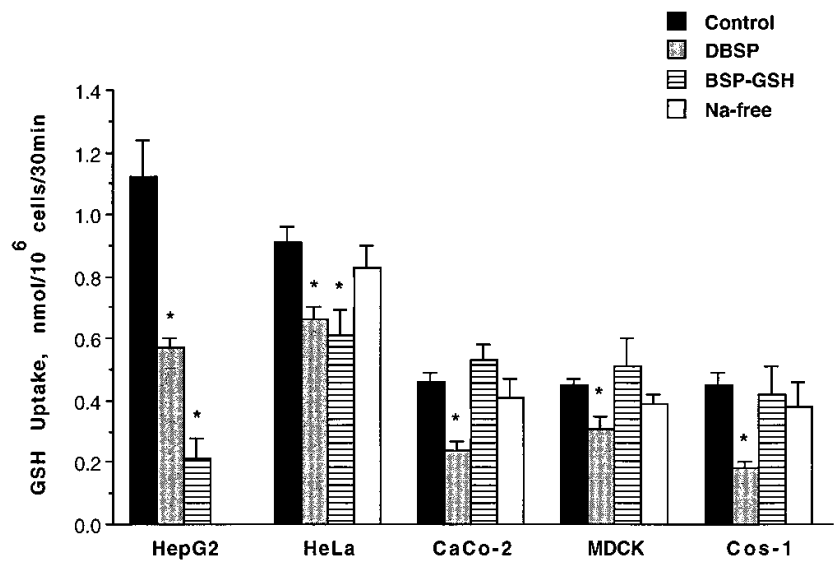

Figure 2. GSH uptake in various cell lines. Cells were transferred $1 \mathrm{~d}$ before experiments from flasks to $60 \times 15$-mm petri dishes. GSH uptake was measured as described in Methods using ${ }^{35} \mathrm{~S}-\mathrm{GSH}$ (plus $1 \mathrm{mM}$ GSH mass) and incubated for $30 \mathrm{~min}$. Effect of DBSP and BSP-GSH was examined by adding these agents $(2 \mathrm{mM})$ to uptake buffer. In $\mathrm{Na}^{+}$-free condition, TMA replaced $\mathrm{Na}^{+}$. Results are expressed as mean \pm SE from 3 to 10 experiments for each cell line. Cell GSH levels (nmol/10 cells) at the end of uptake experiments were not altered by any of these treatments and were (mean \pm SE): HepG $2=$

$19.4 \pm 1.7, \mathrm{HeLa}=19.5 \pm 1.5, \mathrm{CaCo}-2=30.5 \pm 2.5, \mathrm{MDCK}=22.1 \pm 3.3$, Cos $-1=16.8 \pm 1.7$. $* P<0.05$ vs. control by ANOVA.

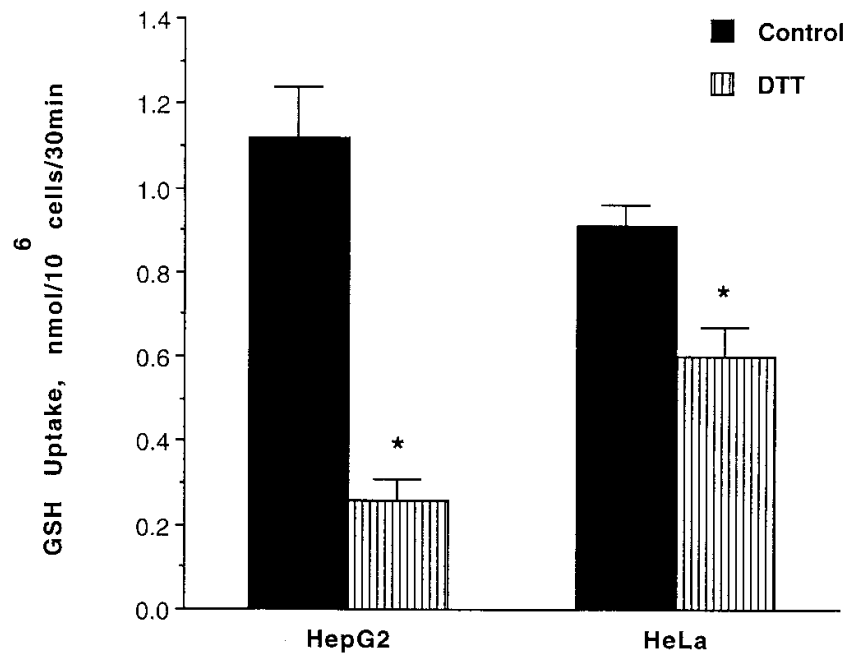

Figure 3. Effect of DTT on GSH uptake in HepG2 and HeLa cells. Cells were pretreated with DTT ( $2 \mathrm{mM}$ for $30 \mathrm{~min}$ ) before measuring GSH uptake as described in Methods. Results are expressed as mean \pm SE from 4 to 6 experiments for each cell line. Cell GSH was not altered by DTT pretreatment and were $($ mean \pm SE): HepG2 = $19.4 \pm 1.7, \mathrm{HeLa}=19.5 \pm 1.5 . * P<0.05$ vs. control by ANOVA.

GSH concentration and uptake with at least two cooperative binding/transporter sites. Therefore, to treat and analyze the data from all cell types uniformly, all fits were done by setting $n=2$ to obtain the $V_{\max }$ and $K_{\mathrm{m}}$ values.

Characterization of the RcGshT and RsGshT $m R N A$ and polypeptide expression in various cell lines. To see the expression of these mRNAs in these cell lines, mRNA from these cells were hybridized with cDNA probes of the RcGshT and RsGshT. Fig. 5 demonstrates the ubiquitous expression of the RcGshT mRNA on a typical Northern blot, but Fig. 6 shows that RsGshT is expressed at more than trace levels only in HepG2 and HeLa cells. Virtual absence of RsGshT in the other three cell lines was not due to inadequate loading of RNA as shown by the housekeeper, GAPD. RcGshT and RsGshT transcripts identified in these cells were identical in size to that observed in rat liver, 4.0 and $2.7 \mathrm{~kb}$, respectively (not shown).

The relative abundance of mRNA in cell lines versus rat liver was then examined using densitometric assessment of Northern blots and equal loading conditions confirmed by probing GAPD as well as by ethidium bromide fluorescence of ribosomal RNA on the gels. Based upon this semiquantitative approach, the relative abundance of RsGshT transcript in HepG2 and HeLa cells was approximately one half of that in rat liver. As for RcGshT, the relative abundance in HepG2 cells was nearly identical to rat liver whereas MDCK, CaCo-2, Cos 1 and HeLa cells expressed between $50-60 \%$ of that in rat liver (results not shown).

We next compared RcGshT-like and RsGshT-like polypeptide expression in these different cell lines. Fig. 7 shows a representative Western blot analysis confirming the presence of RcGshT-like polypeptide of the same size as in rat liver (98 $\mathrm{kD}$ ) in all cell lines but the presence of RsGshT-like polypeptide of the same size as in rat liver $(38 \mathrm{kD})$ in only HepG 2 and HeLa cells. The level of expression of the RsGshT-like polypeptide in HepG2 cells was similar to rat liver whereas ex- 

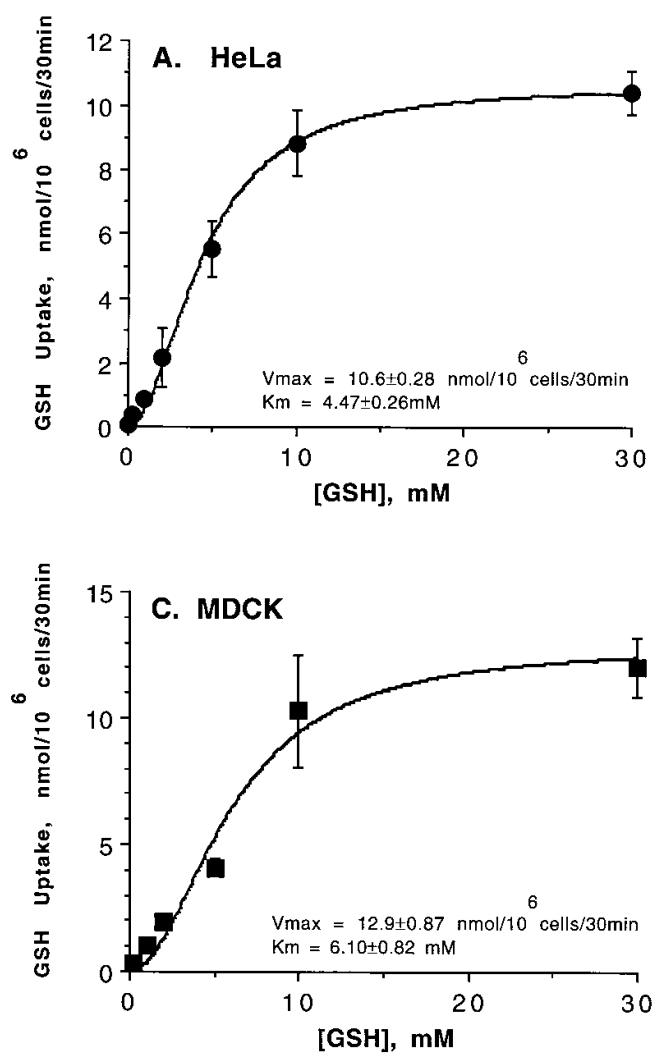

pression of RsGshT-like polypeptide in HeLa cells and RcGshTlike polypeptide in all the cell lines was lower than in rat liver.

Table II summarizes the characteristics of GSH efflux and uptake as well as RcGshT and RsGshT mRNA and polypeptide expression in these five cell lines as compared to rat hepatocytes.

\section{Discussion}

The goal of this study was to establish the magnitude and physiologic characteristics of GSH efflux and uptake in various cell lines and to relate these to the two recently cloned GSH transporters of rat liver. We observed that all of the mammalian cell lines exhibited both efflux and uptake of GSH. The carriermediated nature in this transport is supported by temperature dependence and inhibition of GSH uptake in all cells by DBSP, features which rule out simple diffusion or movement through a channel. The additional more selective inhibition of uptake of GSH by BSP-GSH in HepG2 and HeLa cells sug-

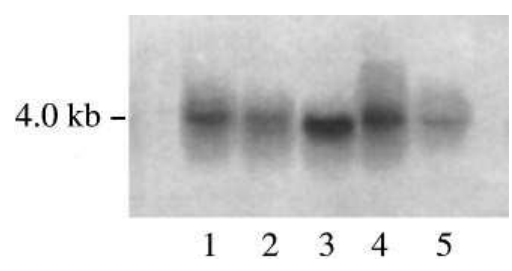

Figure 5. Expression of RcGshT mRNA in various cell lines. RNA (20 $\mu \mathrm{g}$ each lane) samples obtained from MDCK (lane 1), CaCo-2 (lane 2), HeLa (lane 3), HepG2 (lane 4), and Cos-1 (lane 5) were analyzed by Northern blot hybridization with a ${ }^{32} \mathrm{P}$-labeled RcGshT cDNA probe as described in Methods. A representative Northern blot is shown. The position of RcGshT ( $4.0 \mathrm{~kb})$ is as indicated.
B. $\mathrm{CaCO}-2$

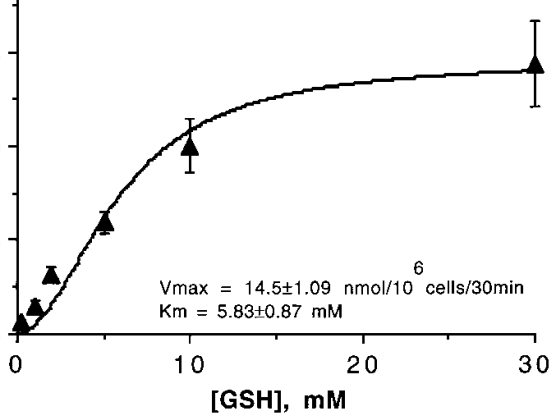

Figure 4. Kinetics of GSH uptake in $(A) \mathrm{HeLa},(B)$ CaCo-2, $(C)$ MDCK, $(D)$ Cos-1 cells. GSH uptake was measured as described in Methods in buffer containing ${ }^{35} \mathrm{~S}$ GSH $(2-6 \mu \mathrm{Ci} / \mathrm{ml}$ per plate) plus $0.2-30 \mathrm{mM}$ GSH. Results are expressed as mean \pm SEM from 4 to 7 experiments. The solid line represents nonlinear least squares computer fits of the Hills equation to the data using the SAAM program with $n=2 . \mathrm{V}_{\text {max }}$ and $K_{\mathrm{m}}$ were determined by the program. Values are mean \pm SD.

gests that the sinusoidal GSH transporter may be present (but does not exclude the additional presence of other GSH transporters). Inhibition by BSP-GSH of GSH efflux requires sufficient uptake of BSP-GSH to cis-inhibit the sinusoidal transporter. HepG2 cells express an independent organic anion uptake mechanism and therefore were able to exhibit this effect (28). Absence of this effect in HeLa cells is due to the fact that they do not have such a system for BSP-GSH uptake (29). The lack of BSP-GSH inhibition of the uptake of GSH by CaCo-2, MDCK, and Cos- 1 cells is consistent with the exclusive expression of the low affinity canalicular GSH transporter, RcGshT. When these results are compared to the presence of the mRNA or polypeptide for either transporter, it is apparent that the canalicular transporter, RcGshT, is expressed in all cells as was seen in Northern blots of RNA from all rat and human organs (4). This appears to be the "univer-

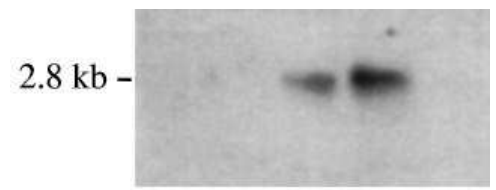

Figure 6. Expression of RsGshT mRNA in various cell lines. RNA $(20 \mu \mathrm{g}$ each lane) samples obtained from MDCK (lane 1), CaCo-2 (lane 2), HeLa

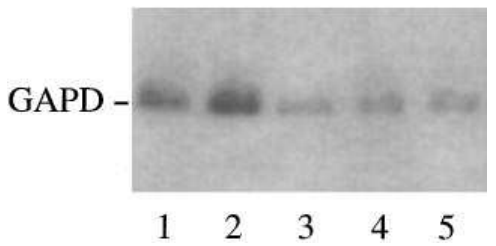
(lane 3), HepG2 (lane 4), and Cos-1 (lane 5) were analyzed by Northern blot hybridization with a ${ }^{32} \mathrm{P}$-labeled RsGshT cDNA probe as described in Methods. The same membrane was then rehybridized with ${ }^{32} \mathrm{P}$-labeled human GAPD cDNA probe. A representative Northern blot is shown. The position of RsGshT (2.8 $\mathrm{kb})$ and GAPD are as indicated. 


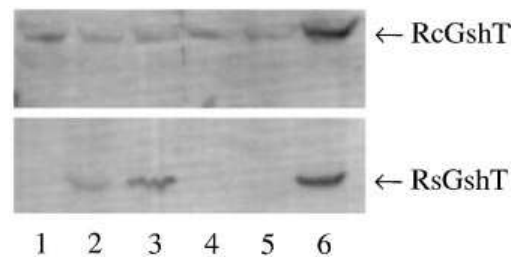

Figure 7. Expression of RcGshT and RsGshTlike polypeptides in various cell lines. A representative Western blot is shown. Protein extracts $(50 \mu \mathrm{g} / \mathrm{lane})$ from Cos-1 (lane 1), HeLa (lane 2), HepG2 (lane

3), MDCK (lane 4), CaCo-2 (lane 5) and rat liver homogenate (lane 6) were analyzed by Western blot analysis using polyclonal antibodies against a RcGshT peptide (top panel) or RsGshT peptide (bottom panel).

sal" GSH transporter in all the cell lines and all rat and human organs. The sinusoidal GSH transporter, RsGshT, is expressed more narrowly and parallels BSP-GSH inhibitable GSH transport. The presence of this liver cell specific transporter in HeLa cells is surprising. Thus, both HepG2 and HeLa cells can serve as useful models to study the concurrent expression of both GSH transporters either in the presence or absence of the separate capacity to take up organic anions, respectively.

A few comments about GSH uptake by cells deserve mention. In other cell types, a $\mathrm{Na}^{+}$-dependent GSH uptake has been suggested $(30,31)$. We found no evidence for this in the cell lines we examined. The finding of $\mathrm{Na}^{+}$-independent GSH uptake reflects the facilitative bidirectional nature of the sinusoidal and canalicular transporters $(3-5,24)$, a property retained in non-hepatocytes expressing these transporters. Thus, in the absence of a driving force for net uptake, such as sodium coupling, the concentration gradient (high intracellular and low extracellular GSH) favors net efflux. The detection of uptake of radioactive GSH most likely reflects exchange with unlabeled intracellular GSH and could be expected to drive net uptake of GSH only when the extracellular GSH concentration exceeds the intracellular. Nevertheless, the assessment of uptake of labeled GSH represents a convenient means to study some of the properties of the carriers, such as inhibitor specificity. Finally, it is important to rule out extracellular hydrolysis and intracellular resynthesis as the explanation for apparent GSH uptake. We used a combination of acivicin, BSO, and excess A and ASC system substrates to accomplish this. BSP-GSH could also act as a competitive substrate for any remaining GGT activity and complicate interpretation of its action. This possibility seems unlikely, however, since the cells in which BSP-GSH exerted no inhibitory effect on GSH uptake exhibited nearly the same levels of expression of GGT as the HeLa cells in which BSP-GSH inhibited uptake. Thus, uptake of radiolabeled GSH represents a convenient means to probe a facilitative transport system.

Consistent with the relative expressions of RcGshT and RsGshT, HepG2 and HeLa cells, two cells that express both RcGshT and RsGshT have $\mathrm{K}_{\mathrm{ms}}$ for GSH uptake that are lower than the cells that express only RcGshT. In fact, cells that express only RcGshT, namely CaCo-2, MDCK and Cos- 1 cells, exhibit near identical $K_{\mathrm{ms}}$ for GSH uptake as RcGshT-cRNA injected oocytes (5). However, a close correlation between the level of expression of the transporters and GSH transport kinetics has not been observed in our studies. Direct comparison between these is made very difficult in view of the potential effects of driving force such as membrane potential, post-translational regulation, membrane physical-chemical properties and uncertainties about species differences in transport kinetics. Thus, our findings are mainly qualitative in showing that cells which express RsGshT or RcGshT exhibit the specific transport characteristics expected with either.

We have previously identified the effects of thiol and disulfide modifiers on GSH efflux and uptake $(7,8)$. Based upon perfused liver studies, these agents act on the sinusoidal carrier but their effects on the canalicular carrier are unknown (7). Furthermore, we could not previously exclude an effect of these agents on all cells due to some nonspecific effect on thiols and disulfides on the cell membrane permeability to GSH diffusion. Therefore, it was of interest to use the new information on the expression of these two transporters in various cell lines to assess the selectivity of thiol-disulfide agents repre-

Table II. Summary of GSH Transport in Mammalian Cell Lines

\begin{tabular}{|c|c|c|c|c|c|c|}
\hline Origin & Rat hepatocyte* & $\begin{array}{c}\text { HepG2* } \\
\text { human hepatoblastoma }\end{array}$ & $\begin{array}{c}\mathrm{HeLa} \\
\text { human cervical Ca }\end{array}$ & $\begin{array}{c}\mathrm{CaCo}-2 \\
\text { human colon } \mathrm{Ca}\end{array}$ & $\begin{array}{c}\text { MDCK } \\
\text { canine kidney-distal tubule }\end{array}$ & $\begin{array}{c}\text { Cos-1 } \\
\text { monkey kidney fibroblast-like }\end{array}$ \\
\hline \multicolumn{7}{|l|}{ GSH efflux } \\
\hline Temp-dependence & yes & yes & yes & yes & yes & yes \\
\hline DTT-stimulated & yes & yes & yes & no & no & no \\
\hline Reversibility of DTT & yes & yes & yes & & & \\
\hline BSP-GSH-inhibitable & yes & yes & no & no & no & no \\
\hline \multicolumn{7}{|l|}{ GSH uptake } \\
\hline Temp-dependence & yes & yes & yes & yes & yes & yes \\
\hline Na-dependence & no & no & no & no & no & no \\
\hline BSP-GSH inhibitable & yes & yes & yes & no & no & no \\
\hline DTT-inhibitable & yes & yes & yes & & & \\
\hline DBSP-inhibitable & yes & yes & yes & yes & yes & yes \\
\hline$K_{\mathrm{m}}(\mathrm{mM})$ & 7.7 & 2.4 & 4.5 & 5.8 & 6.1 & 6.0 \\
\hline \multicolumn{7}{|c|}{ mRNA and polypeptide expression } \\
\hline RcGshT & yes & yes & yes & yes & yes & yes \\
\hline RsGshT & yes & yes & yes & no & no & no \\
\hline
\end{tabular}

*All of the rat and some of the HepG2 data (BSP-GSH effect, temperature and Na-dependence) are based on published work (3-5, 7, 8, 16). 
sented by DTT and cystine. None of the cell lines which exclusively expressed RcGshT and BSP-GSH insensitive GSH uptake were affected by DTT whereas the two cell lines expressing RsGshT and BSP-GSH inhibitable GSH uptake exhibited DTT stimulated efflux. As seen in hepatocytes, this thiol stimulation was partially reversed by cystine and caused a similar shift to increased efflux and decreased uptake. Thus, the activity of the sinusoidal GSH transporter is selectively modified by thiol agents which spare the canalicular transporter. The action of thiol-disulfide agents is to alter RsGshT carrier function and a nonspecific effect on cell permeability to GSH diffusion can be ruled out. RsGshT expressed in HeLa and HepG2 cells retain the same responses to modifiers of transport seen in rat hepatocytes. Thus, the same physiologic characteristics which distinguish the two cloned rat liver GSH transporters can be used to distinguish them in any cell type. In addition to rat liver, kidney (31-33), lung (34) and these cell lines, GSH efflux has been described in diploid cells (35), lymphoid cell lines (36), and astrocytes (37). It remains to be seen if this is accounted for by expression of RcGshT, although this appears to be likely. However, in view of the findings with HeLa cells, the concurrent expression of RsGshT or other unknown GSH transporters remains possible. The ubiquitous downhill efflux of GSH is a carrier-mediated process and is not due to simple diffusion or movement through a nonspecific channel.

A recent report raised the possibility that the multidrugresistance-associated (MRP) protein might transport GSH (38). However, the evidence that MRP transports GSH is indirect and difficult to evaluate since the endogenous GGT was not inhibited and the expression of the latter and RcGshT were not assessed in the MRP-transfected cells (38). Furthermore, there are several lines of evidence that dispute its role as a significant GSH transporter. First, erythrocytes have MRP like activity but do not transport GSH (39) and HeLa cells lack MRP (40) but transport GSH. Second, protein kinase C-mediated phosphorylation greatly stimulates hepatic MRP-like activity and organic anion secretion into bile (41) but inhibits canalicular GSH secretion (42). Third, in diabetic rats there is either an increase or no change in biliary secretion of bilirubin $(43,44)$, which is a substrate for the hepatic MRP-like protein, but a significant decrease in biliary GSH excretion (45). Fourth, BSP-GSH is a substrate for MRP but does not inhibit RcGshT or canalicular GSH secretion (4). Fifth, GSH does not inhibit MRP-mediated ATP-driven GSH S-conjugate (46) and leukotriene $\mathrm{C}_{4}$ transport (personal communication, Dr. D. Keppler). Sixth, MRP is a unidirectional efflux pump (40) whereas GSH transport in cells or in oocytes expressing RcGshT or RsGshT is bidirectional $(4,5,8,24)$. Seventh, MRP-mediated transport is ATP-driven whereas RcGshT-mediated GSH transport is not ATP-dependent (47). The overwhelming bulk of evidence supports the conclusion that MRP and related gene products do not transport GSH. This does not exclude the possibility that they can influence GSH transport. For example, other $\mathrm{ABC}$ transporters are thought to influence ion channels (48), and an analogous effect of MRP on GSH transport is possible. Nevertheless, any speculative role for MRP in GSH transport must take into account the fact that RsGshT and RcGshT are cloned membrane proteins which lead to GSH transport when expressed in oocytes and with the expected characteristics in cell lines reported here.

One additional caveat is worth mentioning. Ballatori and
Dutczak have recently identified a low $K_{\mathrm{m}}$ (high affinity), low $V_{\max } \mathrm{GSH}$ transport component in studies of GSH transport in rat liver canalicular membrane vesicle which seems distinct from RcGshT and RsGshT $(27,49)$. This high affinity component is also inhibited by BSP-GSH. Since it has not been cloned, we cannot definitively prove its presence or absence in the cells studied (especially in HepG2 and HeLa, where BSPGSH inhibited GSH uptake). However, the $\mathrm{K}_{\mathrm{m}}$ for GSH uptake in the cell lines examined are all $>2 \mathrm{mM}$ while the high affinity component described has $K_{\mathrm{m}}$ for GSH uptake of $0.24 \mathrm{mM}$ (27). Furthermore, DIDS inhibited GSH uptake by the high affinity GSH uptake component (27) but had no effect in HepG2 cells. Thus, we can conclude that the BSP-GSH inhibitable transport observed in HepG2 cells is mainly, if not entirely, accounted for by an RsGshT homolog.

Finally, an important question, which remains unanswered, is why do all cells efflux GSH? Since all the cells examined expressed GGT activity, it is conceivable that the efflux of GSH provides substrate for GGT for the purpose of either generating cysteine or other products of transpeptidation (2). Cysteine is extremely unstable with a half-life of seconds in aerobic conditions before being converted to cystine. The best physiologic acceptor in transpeptidation of glutamate from GSH is cystine; the product, $\gamma$-glutamylcystine, if taken up by cells, will be reduced to $\gamma$-glutamylcysteine and cysteine. The former is an obligate precursor of GSH and therefore its extracellular production may regulate intracellular GSH synthesis bypassing the rate limiting $\gamma$-glutamylcysteine synthetase step. Although these processes may appear redundant to the uptake and utilization of cystine, many cells types do not take up cystine and thus require cysteine. In view of its instability, this would require a mechanism for the continuous generation of cysteine. This would depend on GSH release and either hydrolysis or thiol-disulfide exchange with extracellular cystine. Furthermore, the redundancy of these processes for providing GSH precursors underscores the critical importance of maintaining GSH status. In intact rats, much of the plasma GSH, cystine, and cysteine are derived from the efflux of hepatic GSH (50) mediated by RsGshT through an interorgan systemic homeostatic process. In contrast, the ubiquitous role of RcGshT in nearly all tissues and cells could involve maintaining local extracellular GSH, cysteine, cystine, and/or $\gamma$-glutamylcystine in an autocrine or paracrine-like fashion. In liver membrane vesicles, we have previously shown that $\gamma$-glutamyl amino acids cis-inhibit and trans-stimulate GSH transport (24). Thus, another putative role of the GSH transporters is to mediate the uptake of the products of transpeptidation, a process which may be driven by the outwardly directed GSH gradient. This possibility is currently under study in our laboratory.

\section{Acknowledgments}

This work was supported by National Institutes of Health grants DK45334, DK-30312, and V.A. Medical Research Funds. Cells used in Western blot analysis were provided by the Cell Culture Core of the USC Center for Liver Diseases (DK-48522).

\section{References}

1. Kaplowitz, N., T.K. Aw, and M. Ookhtens. 1985. The regulation of hepatic glutathione. Ann. Rev. Pharmacol. Toxicol. 25:715-744.

2. Meister, A. 1988. Glutathione. In The Liver: Biology and Pathobiology, Second Edition. I.M. Arias, W.B. Jakoby, Popper, H., Schachter, D., and D.A. 
Shafritz. Raven Press, Ltd., New York. 401-407.

3. Fernandez-Checa, J.C., Y.R. Yi, C. Garicia-Ruiz, Z. Knezic, S.M. Tahara, and N. Kaplowitz. 1993. Expression of rat liver sinusoidal and canalicular GSH transport systems in xenopus laevis oocytes. J. Biol. Chem. 268:2324-2328.

4. Yi, J., S. Lu, J. Fernandez-Checa, and N. Kaplowitz. 1994. Expression cloning of a rat hepatic reduced glutathione transporter with canalicular characteristics. J. Clin. Invest. 93:1841-1845.

5. Yi, J., S. Lu, J. Fernandez-Checa, and N. Kaplowitz. 1995. Expression cloning of the cDNA for a polypeptide associated with rat hepatic sinusoidal reduced glutathione transport: characteristics and comparison with the canalicular transporter. Proc. Natl. Acad. Sci. USA. 92:1495-1499.

6. Ookhtens, M., I. Lyon, J. Fernandez-Checa, and N. Kaplowitz. 1988. Inhibition of glutathione efflux in the perfused rat liver and isolated hepatocytes by organic anions and bilirubin. Kinetics, sidedness, and molecular forms. $J$. Clin. Invest. 82:608-616.

7. Lu, S.C., J. Ge, H. Huang, J. Kuhlenkamp, and N. Kaplowitz. 1993. Thioldisulfide effects on hepatic GSH transport: Studies in cultured rat hepatocytes and perfused livers. J. Clin. Invest. 92:1188-1197.

8. Lu, S.C., J. Kuhlenkamp, J. Ge, W. Sun, and N. Kaplowitz. 1994. Specificity and directionality of thiol effects on sinusoidal GSH transport in rat liver. Mol. Pharmacol. 46:578-585.

9. Knowles, B.B., C.C. Howe, and D.P. Aden. 1980. Human hepatocellular carcinoma cell lines secrete the major plasma proteins and hepatitis B surface antigen. Science (Wash. DC). 209:497-499.

10. Cepinskas, G., P.R. Kvietys, and T.K. Aw. 1994. $\omega_{3}$-Lipid peroxides injure $\mathrm{CaCo}-2$ cells: relationship to the development of reduced glutathione antioxidant systems. Gastroenterology. 107:80-86.

11. Saito, H., and K. Inui. 1993. Dipeptide transporters in apical and basolateral membranes of the human intestinal cell line CaCo-2. Am. J. Physiol. 265: G289-294.

12. Thwaites, D.T., C.D.A. Brown, B.H. Hirst, and N.L. Simmons. 1993. Transepithelial glycylsarcosine transport in intestinal CaCo-2 cells mediated by expression of $\mathrm{H}^{+}$-coupled carriers at both apical and basal membranes. J. Biol. Chem. 268:7640-7642.

13. Halleux, C., and Y. Schneider. 1994. Iron absorption by CaCo-2 cells cultivated in serum-free medium as in vitro model of the human intestinal epithelial barrier. J. Cell. Physiol. 158:17-28.

14. Haass, C., E.J. Koo, D.B. Teplow, and D.J. Selkoe. 1994. Polarized secretion of $\beta$-amyloid precursor protein and amyloid $\beta$-peptide in MDCK cells. Proc. Natl. Acad. Sci. USA. 91:1564-1568.

15. Ojakian, G.K., R.E. Romain, and R.E. Herz. 1987. A distal nephron glycoprotein that has different cell surface distributions on MDCK cell sublines. Am. J. Physiol. 253:C433-443.

16. Sze, G., N. Kaplowitz, M. Ookhtens, and S.C. Lu. 1993. Bidirectional membrane transport of intact glutathione in Hep G2 cells. Am. J. Physiol. 28: G1128-1134.

17. Tietze, F. 1969. Enzymic method for quantitative determination of nanogram amounts of total and oxidized glutathione: applications to mammalian blood and other tissues. Anal. Biochem. 27:502-522.

18. Fariss, M.W., and D.J. Reed. 1987. High-performance liquid chromatography of thiols and disulfides: dinitrophenol derivatives. Methods Enzymol. 143:101-109.

19. Chomczynski, P., and N. Sacchi. 1987. Single-step method of RNA isolation by acid guanidinium thiocyanate-phenol-chloroform extraction. Anal. Biochem. 162:156-159.

20. Hopp, T.P., and K.R. Woods. 1981. Prediction of protein antigenic determinants from amino acid sequences. Proc. Natl. Acad. Sci. USA. 78:38243828 .

21. Laemmli, U.K. 1970. Cleavage of structural proteins during the assembly of the head of bacteriophage T4. Nature (Lond.). 227:680-685.

22. Towbin, H., T. Staehein, and J. Gordon. 1989. Electrophoretic transfer of proteins from polyacrylamide gels to nitro-cellulose sheets: procedure and some applications. Proc. Natl. Acad. Sci. USA. 76:4350-4354.

23. Meier, P.J., E.S. Sztul, A. Reuben, and J.L. Boyer. 1984. Structural and functional polarity of canalicular and basolateral plasma membrane vesicles isolated in high yield from rat liver. J. Cell Biol. 98:991-1000.

24. Garcia-Ruiz, C., J.C. Fernandez-Checa, and N. Kaplowitz. 1992. Bidirectional plasma membrane transport of reduced glutathione in intact hepatocytes and membrane vesicles. J. Biol. Chem. 267:22256-22264.

25. Lu, S.C., and H. Huang. 1994. Comparison of sulfur amino acids utilization for GSH synthesis in HepG2 cells and rat hepatocytes. Biochem. Pharm. 47:859-869.

26. Ballatori, N., and T.W. Clarkson. 1985. Sulfobromophthalein inhibition of glutathione and methylmercury secretion into bile. Am. J. Physiol. 11:G238-245.
27. Ballatori, N., and W.J. Dutczak. 1994. Identification and characterization of high and low affinity transport systems for reduced glutathione in liver cell canalicular membranes. J. Biol. Chem. 269:19731-19737.

28. Min, A.D., T. Goeser, R. Liu, C.G. Campbell, P.M. Novikoff, A.W. Wolkoff. 1991. Organic Anion Transport in HepG2 cells: Absence of the Highaffinity, Chloride-dependent Transporter. Hepatology. 14:1217-1223.

29. Shi, X., S. Bai, A.C. Ford, R.D. Burk, E. Jacquemin, B. Hagenbuch, P.J. Meier, and A.W. Wolkoff. 1995. Stable inducible expression of a functional rat liver organic anion transport protein in HeLa cells. J. Biol. Chem. 270:2559125595.

30. Hagen, T.M., and D.P. Jones. 1987. Transepithelial transport of glutathione in vascularly perfused small intestine of rat. Am. J. Physiol. 252:G607613.

31. Lash, L.H., and D.P. Jones. 1984. Renal glutathione transport. characteristics of the sodium-dependent system in the basal-lateral membrane. J. Biol. Chem. 259:14508-14514.

32. Hagen, T.M., T.K. Aw, and D.P. Jones. 1988. Glutathione uptake and protection against oxidative injury in isolated kidney cells. Kidney International. 34:74-81.

33. Scott, R.D., R.P. Hughey, and N.P. Curthoys. 1993. Role of apical and basolateral secretion in turnover of glutathione in LLC-PK 1 cells. Am. J. Physiol. 265:F723-728.

34. Hagen, T.M., L.A. Brown, and D.P. Jones. 1986. Protection against paraquat-induced injury by exogenous GSH in pulmonary alveolar type II cells. Biochem. Pharmacol. 35:4537-4542.

35. Bannai, S., and H. Tsukeda. 1979. The export of glutathione from human diploid cells in culture. J. Biol. Chem. 254:3444-3450.

36. Griffith, O.W., A. Novogrodsky, and A. Meister. 1979. Translocation of glutathione from lymphoid cells that have markedly different $\gamma$-glutamyl transpeptidase activities. Proc. Natl. Acad. Sci. USA. 76:2249-2252.

37. Yudkoff, M., D. Pleasure, L. Cregar, Z.P. Lin, I. Nissim, J. Stern, and I. Nissim. 1990. Glutathione turnover in cultured astrocytes: studies with $\left[{ }^{15} \mathrm{~N}\right]$ glutamate. J. Neurochemistry. 55:137-145.

38. Zaman, G.R., J. Lankelma, O. van Tellingen, J. Beijnen, H. Dekker, C. Paulusma, R.P.J. Oude Elferink, F. Baas, and P. Borst. 1995. Role of glutathione in the export of compounds from cells by the multidrug-resistanceassociated protein. Proc. Natl. Acad. Sci. USA. 92:7690-7694.

39. Kondo, T., G.L. Dale, and E. Beutler. 1980. Glutathione transport by inside-out vesicles from human erythrocytes. Proc. Natl. Acad. Sci. USA. 77: 6359-6362.

40. Leier, I., G. Jedlitschky, U. Buchholz, S.P.C. Cole, R.G. Deeley, and D. Keppler. 1994. The MRP gene encodes an ATP-dependent export pump for leukotriene C4 and structurally related conjugates. J. Biol. Chem. 269:2780727810.

41. Roelofsen, H., R. Ottenhoff, R.P. Oude Elferink, and P.L. Jansen. 1991 Hepatocanalicular organic-anion transport is regulated by protein kinase $\mathrm{C}$. Biochem. J. 278:637-641.

42. Raiford, D.S., A.M. Sciuto, and M.C. Mitchell. 1991. Effects of vasopressor hormones and modulators of protein kinase $\mathrm{C}$ on glutathione efflux from perfused rat liver. Am. J. Physiol. 24:G578-584.

43. Tuñon, M.J., P. Gonzalez, L.A. Garcia-Pardo, and J. Gonzalez. 1991. Hepatic transport of bilirubin in rats with streptozotocin-induced diabetes. $J$. Hepatology. 13:71-77.

44. Watkins, J.B., and S.E. Sherman. 1992. Long-term diabetes alters the hepatobiliary clearance of acetaminophen, bilirubin and digoxin. J. Pharmacol. Exp. Ther. 260:1337-1343.

45. Lee, S., N. Kaplowitz, and S.C. Lu. 1994. Impaired canalicular GSH transport in diabetic rats. Gastroenterology. 106:A991.

46. Kobayashi, K., Y. Sogame, H. Hara, and K. Hayashi. 1990. Mechanism of glutathione S-conjugate transport in canalicular and basolateral rat liver plasma membranes. J. Biol. Chem. 265:7737-7741.

47. Fernández-Checa, J.C., H. Takikawa, T. Horie, M. Ookhens, and N. Kaplowitz. 1992. Canalicular transport of reduced glutathione in normal and mutant eisai hyperbilirubinemic rats. J. Biol. Chem. 267:1667-1673.

48. Inagaki, N., T. Gonoi, J.P. Clement IV, N. Namba, J. Inazawa, G. Gonzalez, L. Aguilar-Bryan, S. Seino, and J. Bryan. 1995. Reconstitution of $\mathrm{I}_{\mathrm{KATP}}:$ An inward rectifier subunit plus the sulfonylurea receptor. Science (Wash. DC). 270:1166-1170.

49. Dutczak, W.J., and N. Ballatori. 1994. Transport of the glutathionemethylmercury complex across liver canalicular membranes on reduced glutathione receptors. J. Biol. Chem. 269:9746-9751.

50. Ookhtens, M., A.V. Mittur, and N.A. Erhart. 1994. Changes in plasma glutathione concentrations, turnover, and disposal in developing rats. Am. J. Physiol. 266:R979-R988. 